\title{
Understanding the Employee's Intention to Use Information System: Technology Acceptance Model and Information System Success Model Approach
}

\author{
S. MARTONO ${ }^{1}$, Ahmad NURKHIN ${ }^{2}$, Hasan MUKHIBAD ${ }^{3}$, Indah ANISYKURLILLAH ${ }^{4}$, \\ Christian Wiradendi WOLOR
}

Received: August 01, 2020 Revised: September 06, 2020 Accepted: September 10, 2020

\begin{abstract}
This study aims to understand the determinant of the employee's intention to use information system within the framework of the Technology Acceptance Model (TAM) and Information System Success Model (ISSM). This paper also aims to examine the influence of ISSM dimension on the perceived usefulness and the perceived ease of use. The research respondents were 248 employees of Universitas Negeri Semarang (UNNES) who are users of the Financial Information System (SIKEU). Data was obtained using a questionnaire that was distributed online via Google form. The data analysis method used is Structural Equation Model (SEM) analysis using the Warp-PLS software. The results showed that the dimensions of TAM (perceived ease of use and perceived usefulness) had a positive and significant influence on the employee's intention to use SIKEU. The ISSM dimension (system quality and information quality) also had a significant influence, although other ISSM dimensions (service quality) had not been proven to have a significant influence on the employee's intention to use SIKEU. Moreover, the results showed that the employee's intention to use is a determinant of SIKEU's actual usage. Perceived ease of use was significantly determined by system quality, information quality, and service quality. In addition, the perceived usefulness was significantly determined by system quality and information quality.
\end{abstract}

Keywords: Technology Acceptance Model, Information System Success Model, Financial Information System, Employee's Intention

JEL Classification Code: M12, M14, D83, L86

\section{Introduction}

${ }^{1}$ First Author and Corresponding Author. Lecturer, Faculty of Economics, Universitas Negeri Semarang, Indonesia [Postal Address: L2 Building, Sekaran Campus, Gunung Pati, Semarang, Central Java, 50229, Indonesia] Email: martono@mail.unnes.ac.id ${ }^{2}$ Lecturer, Faculty of Economics, Universitas Negeri Semarang, Indonesia. E-mail: ahmadnurkhin@mail.unnes.ac.id

${ }^{3}$ Lecturer, Faculty of Economics, Universitas Negeri Semarang, Indonesia. E-mail: hasanmukhibad@mail.unnes.ac.id

${ }^{4}$ Lecturer, Faculty of Economics, Universitas Negeri Semarang, Indonesia. E-mail: indah_anis@mail.unnes.ac.id

${ }^{5}$ Lecturer, Faculty of Economics, Universitas Negeri Jakarta, Indonesia. E-mail: christianwiradendi@unj.ac.id

(C) Copyright: The Author(s)

This is an Open Access article distributed under the terms of the Creative Commons Attribution Non-Commercial License (https://creativecommons.org/licenses/by-nc/4.0/) which permits unrestricted non-commercial use, distribution, and reproduction in any medium, provided the original work is properly cited.
The development of information technology is very rapid, including its usage in higher education institutions. The usage is not only to improve the quality of learning, but also to improve the quality of higher education performance. Higher education management should be able to manage their resources by utilizing information technology. Higher education performance will be better because utilizing information technology can increase the effectiveness and efficiency of the work done by employees. Higher education management must be adaptable to information technology by developing internet-based information systems in all existing fields.

Many higher education institutions have developed information systems, including the management of higher education finances. The goal is to increase the accountability and transparency of higher education financial management. Another goal is to provide the data needed by users (especially employees, both lecturers and education staff) quickly and 
accurately. However, many users only take advantage of the information system without wanting to provide input for the system to be developed even better. Information systems developers cannot grasp user needs.

Studies on the development of information systems in higher education have focused on developing systems used to support learning. Pal'Ova, Vejacka, and Kakalejcik (2020) have developed Project-Based Learning and a virtual laboratory to support entrepreneurship education. Cahyono \& Munawar (2020) developed Massive Open Online Courses (MOOCs) of Universitas Negeri Semarang (UNNES) which can be used for the implementation of cross-institutional lectures with a credit transfer scheme. Meanwhile, Ma (2020) developed an online sports learning model using computer technology as a means of learning physical education.

We consider that the need for information systems in higher education institutions is not only for the academic field, but also in the service system provided by all employees in providing information on the payroll system provided to employees. This system is needed to provide information about how much of the total pay is calculated for salaries, remuneration, and other rewards received by the employees. This information is needed to support the transparency of the payroll system and this is important to support employee satisfaction and productivity (Hameed et al., 2014). To realize this goal, UNNES has developed a financial information system (SIKEU) (Martono et al., 2020).

There are several approaches to understand the intentions and behaviors of the use of information systems by users in the context of the education world. These model include the Technology Acceptance Model (TAM) developed by (Davis, 1989), Unified Theory of Acceptance and Use of Technology (UTAUT) developed by (Venkatesh et al., 2003), and information system success model (DeLone \& McLean, 1992). Many researchers have used TAM to understand the intentions and behaviors of the use of information technology by users in the context of learning (Camilleri \& Camilleri, 2019; Kardoyo et al., 2015; Lestari \& Indrasari, 2019; Schöpfel et al., 2019), UTAUT (Muhsin et al., 2016; Samsudeen, 2019; Wu \& Wu, 2019) and ISSM (Chen et al., 2016; Huang et al., 2015; Masrek \& Gaskin, 2016).

The purpose of this study is to understand the employee's intention of using the Financial Information System (SIKEU) developed by the Universitas Negeri Semarang (UNNES) using TAM and ISSM. Research that uses TAM and ISSM together to understand the intention of using financial information systems in higher education is very interesting. The findings will understand user behavior and are important for further system development.

\section{Literature Review and Hypotheses Development}

\subsection{The Concept of Technology Acceptance Model (TAM) and Information System Success Model (ISSM)}

Technology Acceptance Model (TAM) was initiated by Davis et al., 1989 and developed from the theory of reasoned action (TRA) proposed by Fishbein and Ajzen (1975) in Social Psychology (Kardoyo et al., 2015). The main idea of TAM is to investigate and evaluate the relationship of actual behavior, behavioral intentions, attitudes, subjective norms and beliefs. In 1993 the TAM model was reorganized to understand the use and acceptance of information systems (Chen et al., 2016). Many researchers then use TAM by adding other variables like gender and individual differences such as levels of education and participation in educational training.

The Information System Success Model or ISSM developed by DeLone and McLean in 1992 consists of six dimensions: system quality, information quality, system use, user satisfaction, impact on individuals, and impact on organizations (DeLone \& McLean, 1992). The ISSM model describes system quality and information quality as having a joint or partial influence on the user satisfaction and system use. System use can influence user satisfaction (Fang et al., 2011).

The original ISSM model was then revised and updated in 2003. There is an additional dimension, i.e. service quality and net benefits. Service quality will influence users to continue using the information system and for them to get satisfaction. Net benefits replace the dimensions of impact on individual and impact on organization. Net benefits can influence both the intention to use and user satisfaction (DeLone \& McLean, 2003). They believe that a high-quality system will be more usable, more satisfying, and have many benefits for the user. Three quality factors (system quality, service quality, and information quality) should have a positive influence on the intention to use, actual system usage, and user satisfaction. (Masrek \& Gaskin, 2016).

\subsection{Understanding Employee's Intention to Use SIKEU Using TAM}

The development of information technology has changed many aspects of the world, including business management (Q. B. Le et al., 2020). There are some methods to understand the user behavior to use information technology. To explain individual technology acceptance behavior, TAM argues that a person's attitude towards the use of target 
technology is influenced by the person's perception of the ease and usefulness of the technology (Byun, 2018). TAM explains that an individual will use information technology (information systems) if the individual is influenced by two factors, i.e. the extent to which the system is considered to have perceived usefulness and the level of ease of use of information systems (perceived ease of use). Willingness level will influence an individual's level of use of information system.

Perceived usefulness will influence the intention to use SIKEU. UNNES employees will continue to use SIKEU because they perceive that SIKEU has benefits. UNNES employees can use SIKEU for various purposes such as obtaining information about the income received and deductions for the income. In addition, UNNES employees are required to use SIKEU when traveling on business. Thus, the higher the benefits obtained from the information system, the higher the user's intention to continue to use it. The higher the intention, the higher the level of use of the information system. Many researchers have proven that perceived usefulness has a significant impact on intention to use. This is in line with the results of previous studies (Ahmed \& Akhlaq, 2015; Camilleri \& Camilleri, 2019; Kesharwani \& Bisht, 2012; J. (Sunny) Kim, 2016; T. Kim \& Chiu, 2018; Lin, 2013; O. T. Nguyen, 2020; Park \& Kwon, 2016; Yadav et al., 2015).

Perceived ease of use also effects on the employee's intention to use SIKEU significantly. SIKEU users will continue to use SIKEU if SIKEU is easy to use, simple, and hassle-free. An easy to use information system will be more often used by its users. Users will not use the system if the features are complex even though they are very useful. The employee's intention to use SIKEU will affect significantly on the level of SIKEU usage. This is in line with the results of previous research which has proven that intention to use is affected by perceived ease of use. Previous researchers have also found the same results (Ahmed \& Akhlaq, 2015; T. Kim \& Chiu, 2018; Lin, 2013; Martono et al., 2020). However, there are different findings that perceived ease of use has no impact on intention to use (Camilleri \& Camilleri, 2019; Kesharwani \& Bisht, 2012; J. (Sunny) Kim, 2016). Intention to use will also influence actual use (Martono et al., 2020). Based on this explanation, the research hypotheses that can be developed are as follows:

H1: perceived usefulness has a positive and significant impact on the employee's intention to use SIKEU

H2: perceived ease of use has a positive and significant impact on the employee's intention to use SIKEU

H3: the employee's intention to use SIKEU has a positive and significant impact on SIKEU usage

\subsection{Understanding the Employee's Intention to Use SIKEU Using ISSM}

ISSM describes how to assess the use of information systems. A good and successful information system is used by users if it has good quality (system quality, information quality, and service quality). The three dimensions of quality will influence users to continue using the information system.

System quality shows the quality of the information system. The better the quality of the system, the more users will intend to continue using it. System quality is usually measured in terms of ease of understanding, ease of use, and speed and accuracy of responses and results. Information quality is an evaluation of the output of the information system (Huang et al., 2015). Information produced by an information system is said to be of quality if it meets the following dimensions: information and user interface is easy to understand, the information presented is clear and easy to read, and the information is useful. Users will continue to use SIKEU if SIKEU is able to produce the information users need, is correct, and easy to understand. Service quality is based on an evaluation of the performance of the information system provider and includes responsiveness, assurance, and friendliness (DeLone \& McLean, 2003). System providers who are said to have quality service are those who are able to provide answers (responses) quickly to users, master relevant and credible knowledge, and are able to interact with users in a more pleasant, thoughtful, and attentive manner. The three ISSM predictors proved to have a significant influence on system use (Huang et al., 2015).

This study also integrates the dimensions of ISSM and TAM. Thus, the study tests the relationship between system quality, information quality, and service quality against perceived usefulness and perceived ease of use. The three ISSM dimensions are the determining factors for the two TAM dimensions. The results of previous studies indicate that service quality is able to influence perceived usefulness (Park \& Kwon, 2016) and perceived of ease of use (Chen et al., 2016; Park \& Kwon, 2016). Based on this description, the research hypotheses developed are as follows.

H4: system quality has a positive and significant influence on the employee's intention to use SIKEU

H5: information quality has a positive and significant influence on the employee's intention to use SIKEU

H6: service quality has a positive and significant influence on the employee's intention to use SIKEU

H7: system quality has a positive and significant influence on perceived usefulness

H8: information quality has a positive and significant influence on perceived usefulness 
H9: service quality has a positive and significant influence on perceived usefulness

H10: system quality has a positive and significant influence on perceived ease of use

H11: information quality has a positive and significant influence on perceived ease of use

H12: service quality has a positive and significant influence on perceived ease of use

Figure 1 shows the framework of the research.

\section{Research Methods}

The research was conducted in 2019 with the employees (lecturers and education staff) of UNNES who are SIKEU users and the research respondents, as well. This study obtained 250 completed questionnaires.

The dependent variable in the main research model comprises SIKEU Usage and the employee's intention to use SIKEU. The independent variables are the dimensions of the TAM model (perceived ease of use and perceived usefulness) and ISSM (system quality, information quality, and service quality). SIKEU Usage shows the extent to which UNNES employees use SIKEU. The employee's intention to use SIKEU refers to the level of willingness of UNNES employees to continue using SIKEU. The perceived ease of use shows the level of ease in using SIKEU. Perceived usefulness means the perceived benefit level of SIKEU for UNNES employees. System quality shows the quality level of SIKEU as an information system. Information quality is the level of quality of information presented and provided by SIKEU. Meanwhile, service quality shows the level of service quality of the SIKEU admin in solving problems faced by users.

The data was collected using a questionnaire which was distributed via email to respondents and by utilizing the google form feature. The questionnaire has been developed from previous studies. The data obtained was analyzed using SEM (structural equation model) analysis. The software used for data analysis was WarpPLS.

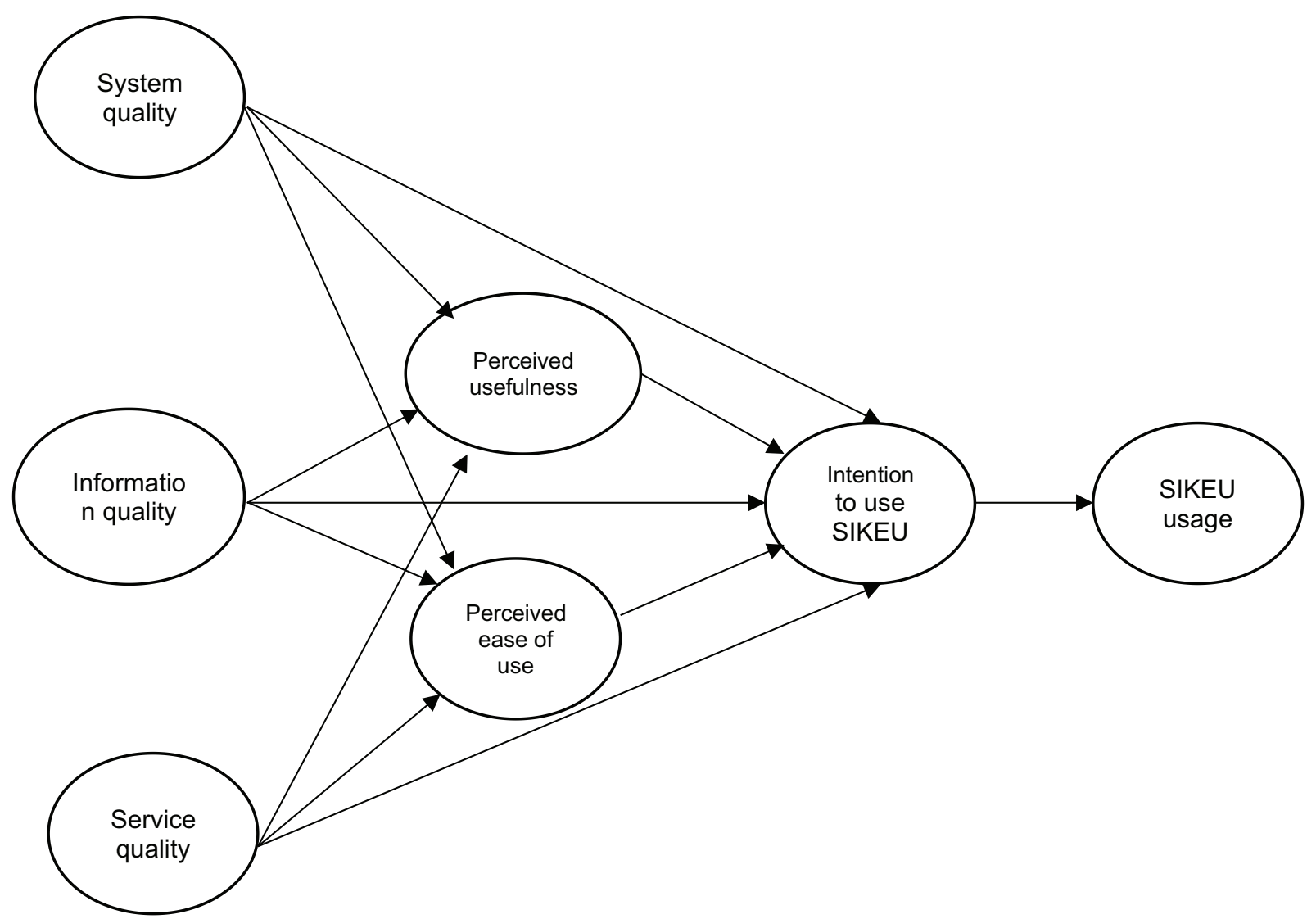

Figure 1. Conceptual Framework 


\section{Result and Discussion}

Researchers processed the data obtained using the WarpPLS application. The researchers tested the validity and reliability of the research instrument first. The results of the fit and quality model test show that the Average Path Coefficient $(\mathrm{APC})=0.245, \mathrm{P}<0.001$. Average R-squared $(\mathrm{ARS})=0.447, \mathrm{P}<0.001$. Average adjusted R-squared $(\mathrm{AARS})=0.440, \mathrm{P}<0.001$. and Average block VIF (AVIF) $=2.937$, acceptable if $<=5$, ideally $<=3.3$. The value of the four indicators shows that the research model can be declared fit or it fulfills further analysis (hypotheses testing).

The results of hypotheses testing through path analysis can be seen in Table 1 below. The path coefficient of the perceived usefulness on the employee's intention to use SIKEU is 0.114 with a probability $(\mathrm{P})$ value $=0.034$. This means that the perceived usefulness has a positive and significant influenee impact on the employee's intention to use SIKEU. The path coefficient for the perceived ease of use on the employee's intention to use is 0.177 with a $\mathrm{P}$ value $=0.002$. This proves that the perceived ease of use has a significant impact on the employee's intention to use SIKEU. Meanwhile, the path coefficient of the employee's intention to use SIKEU against SIKEU usage (actual use) is 0.697 with a $\mathrm{P}$ value $<0.001$. Thus, the intention to use SIKEU is proven to have a positive and significant impact on SIKEU usage.

The results of the next study are to understand the relationship between the ISSM dimensions and the intention to use SIKEU. The system quality path coefficient on the employee's intention to use is 0.352 with a $\mathrm{P}$ value $<0.001$. This means that system quality has a positive and significant impact on the intention to use SIKEU. The information quality path coefficient on the intention to use SIKEU is 0.126 with a $\mathrm{P}$ value $=$ 0.022 . This shows that information quality has a positive and significant influence on the intention to use SIKEU. Meanwhile, the service quality path coefficient on the intention to use SIKEU is 0.061 with a $\mathrm{P}$ value $=0.165$. This means that service quality does not have a significant influence on the intention to use SIKEU.

This study also examined the relationship between the ISSM dimension and the TAM dimension. The test results showed that system quality, information quality, and service quality were proven to have a positive and significant influence on the perceived usefulness. The path coefficients of the three dimensions were 0.196 , 0.289 , and 0.166 with $P$ values of $<0.001,<0.001$ and 0.004 , respectively. information quality has a stronger influence on the perceived usefulness because the path coefficient is greater than the system quality and service quality.

The next results show that system quality and information quality were proven to have a significant influence on the perceived ease of use. The path coefficients were 0.326 and 0.425 with a $\mathrm{P}$ value $<0.001$. However, service quality was not proven to have a significant influence on the perceived ease of use. The path coefficient is 0.016 with a $P$ value of 0.401 .

Table 1: Results of the structural model analysis

\begin{tabular}{|c|c|c|c|}
\hline Research hypotheses & $\begin{array}{c}\text { Path } \\
\text { coefficient }\end{array}$ & $P$ value & Result \\
\hline H1. Perceived Usefulness $\rightarrow$ the employee's intention to use SIKEU & 0.114 & 0.034 & Supported \\
\hline H2. Perceived Ease of use $\rightarrow$ the employee's intention to use SIKEU & 0.177 & 0.002 & Supported \\
\hline H3. the employee's intention to Use SIKEU $\rightarrow$ SIKEU Usage & 0.697 & $<0.001$ & Supported \\
\hline H4. System quality $\rightarrow$ the employee's intention to use SIKEU & 0.352 & $<0.001$ & Supported \\
\hline H5. Information quality $\rightarrow$ the employee's intention to use SIKEU & 0.126 & 0.022 & Supported \\
\hline H6. Service quality $\rightarrow$ the employee's intention to use SIKEU & 0.061 & 0.165 & Not supported \\
\hline H7. System quality $\rightarrow$ Perceived Usefulness & 0.196 & $<0.001$ & Supported \\
\hline H8. Information quality $\rightarrow$ Perceived Usefulness & 0.289 & $<0.001$ & Supported \\
\hline H9. Service quality $\rightarrow$ Perceived Usefulness & 0.166 & 0.004 & Supported \\
\hline H10. System quality $\rightarrow$ Perceived Ease of use & 0.326 & $<0.01$ & Supported \\
\hline H11. Information quality $\rightarrow$ Perceived Ease of use & 0.425 & $<0.01$ & Supported \\
\hline H12. Service quality $\rightarrow$ Perceived Ease of use & 0.016 & 0.401 & Not Supported \\
\hline
\end{tabular}




\subsection{Understanding the Employee's Intention to Use SIKEU Using TAM}

The results show that the TAM dimension is proven to have a positive and significant influence on the employee's intention to use SIKEU. The results of this study support the results of previous studies that indicate the intention to use is significantly influenced by the perceived usefulness (Ahmed \& Akhlaq, 2015; Byun, 2018; Camilleri \& Camilleri, 2019; H. B. H. Le et al., 2020; O. T. Nguyen, 2020; X. T. Nguyen $\&$ Luu, 2020; Park \& Kwon, 2016) and the perceived of ease of use (Ahmed \& Akhlaq, 2015; H. B. H. Le et al., 2020; Martono et al., 2020; X. T. Nguyen \& Luu, 2020). Other results also show that the intention to use is significant on SIKEU usage, the same as the findings of previous researchers (H. B. H. Le et al., 2020; Martono et al., 2020).

The employees' intention to use SIKEU and actual use of SIKEU is strongly influenced by the perceived usefulness and the perceived ease of users. This means that the more useful and easier an information system is, the more users intend to continue to take advantage of the system. Finally, the system is used properly. The results of this study confirm TAM.

\subsection{Understanding the Employee's Intention to Use SIKEU Using ISSM}

The ISSM dimension was not fully proven to have a significant influence on the intention to use SIKEU. Only system quality and information quality can be a predictor of the intention to use SIKEU. Meanwhile, service quality is not proven to have a significant influence on the intention to use SIKEU. This is different from the findings of previous researchers who found a significant influence of service quality (Huang et al., 2015). The results of this study mean that SIKEU users do not care about the quality of service provided by the admin. SIKEU users consider SIKEU to meet quality in system and information. SIKEU users do not find significant obstacles in using SIKEU and they can solve problems without going through the SIKEU admin service.

The relationship between the TAM and ISSM models were also tested in this study. The ISSM dimension was tested as a predictor of the TAM dimension. The results showed that the ISSM dimension was proven to be significant as a determinant of the perceived usefulness. The results of this study are the same as the findings of previous researchers who found a significant influence on the perceived usefulness (Park \& Kwon, 2016). However, the ISSM dimension did not fully have a significant influence on perceived ease of use because service quality was not proven to be a predictor. The results of previous studies indicate that service quality can influence the perceived ease of use positively and significantly (Chen et al., 2016; Park \& Kwon, 2016).

\section{Conclusion}

This study seeks to understand the factors behind the employee's intention of using SIKEU from the perspective of ISSM and TAM. The results show that the TAM dimension can be understood as a predictor of the employee's intention to use SIKEU. Perceived usefulness and perceived ease of use have a significant influence on the employee's intention to use SIKEU. However, the ISSM dimension is not fully proven as a factor that influences the employee's intention to use SIKEU. Service quality has not proven to be a predictor of the employee's intention to use SIKEU. The ISSM dimension can be understood as a determining factor for the perceived usefulness, but not for the perceived ease of use. There is no significant influence of service quality on perceived ease of use.

Studies on testing the acceptance and utilization of the information system are still very interesting to do. Many concepts and perspectives can be used to better understand user behavior and user behavior is more unique and interesting to understand.

\section{References}

Ahmed, E., \& Akhlaq, A. (2015). Digital commerce in emerging economies: Factors associated with online shopping intentions in Pakistan. International Journal of Emerging Markets, 10(4), 634-647. https://doi.org/10.1108/IJoEM-01-2014-0051

Byun, S. (2018). Evaluating information technology systems using consumer surveys: The role of personal product knowledge. Journal of Asian Finance, Economics and Business, 5(4), 117-125. https://doi.org/10.13106/jafeb.2018.vol5.no4.117

Cahyono, A. N., \& Munawar, A. (2020). UNNES MOOCs: What strengths does the University have and the society needs? Journal of Physics: Conference Series, 1567(3). https://doi. org/10.1088/1742-6596/1567/3/032026

Camilleri, M. A., \& Camilleri, A. C. (2019). The students' readiness to engage with mobile learning apps. Interactive Technology and Smart Education. https://doi.org/10.1108/ITSE-06-2019-0027

Chen, J. F., Chang, J. F., Kao, C. W., \& Huang, Y. M. (2016). Integrating ISSM into TAM to enhance digital library services: A case study of the Taiwan digital meta-library. Electronic Library, 34(1), 58-73. https://doi.org/10.1108/EL-01-20140016

Davis, F. D. (1989). Perceived usefulness, perceived ease of use, and user acceptance of information technology. MIS Quarterly, 13(3), 319-339. https://doi.org/10.2307/249008

DeLone, W. H., \& McLean, E. R. (1992). Information systems success: The quest for the dependent variable. Information Systems Research, 3(1), 60-95. https://doi.org/10.1287/isre.3.1.60

DeLone, W. H., \& McLean, E. R. (2003). The DeLone and McLean model of information systems success. Journal of Management 
Information Systems, 19(4), 9-30. https://doi.org/10.1080/0742 1222.2003.11045748

Fang, Y. H., Chiu, C. M., \& Wang, E. T. G. (2011). Understanding customers' satisfaction and repurchase intentions. Internet Research, 21(4), 479-503. https://doi. org/10.1108/10662241111158335

Hameed, A., Ramzan, M., Zubair, H. M. K., Ali, G., \& Arslan, M. (2014). Impact of compensation on employee performance (Empirical evidence from banking sector of Pakistan). International Journal of Business and Social Science, 5(2), 302-309.

Huang, Y. M., Pu, Y. H., Chen, T. S., \& Chiu, P. S. (2015). Development and evaluation of the mobile library service system success model: A case study of Taiwan. The Electronic Library, 33(6), 1174-1192.

Kardoyo, K., Nurkhin, A., \& Arief, S. (2015). The determinants of student's intention to use mobile learning. PEOPLE: International Journal of Social Sciences, Special Issue, 102-117.

Kesharwani, A., \& Bisht, S. S. (2012). The impact of trust and perceived risk on internet banking adoption in India: An extension of technology acceptance model. International Journal of Bank Marketing, 30(4), 303-322. https://doi. org/10.1108/02652321211236923

Kim, J. (2016). An extended technology acceptance model in behavioral intention toward hotel tablet apps with moderating effects of gender and age. International Journal of Contemporary Hospitality Management, 28(8), 1535-1553. https://doi.org/10.1108/IJCHM-06-2015-0289

Kim, T., \& Chiu, W. (2018). Consumer acceptance of sports wearable technology: The role of technology readiness. International Journal of Sports Marketing and Sponsorship, 20(1), 109-126 https://doi.org/10.1108/IJSMS-06-2017-0050

Le, H. B. H., Ngo, C. T., Trinh, T. T. H., \& Nguyen, T. T. P. (2020). Factor affecting customers' decision to use mobile banking service: A case of Thanh Hoa province, Vietnam. Journal of Asian Finance, Economics and Business, 7(2), 205-212. https://doi.org/10.13106/jafeb.2020.vol7.no2.205

Le, Q. B., Nguyen, M. D., Bui, V. C., Mai, T., \& Dang, H. (2020). The Determinants of management information systems effectiveness in small- and medium-sized enterprises. Journal of Asian Finance, Economics and Business, 7(8), 567-576. https://doi.org/10.13106/jafeb.2020.vol7.no8.567

Lestari, N. N., \& Indrasari, S. Y. (2019). Teachers' adoption of $1: 1$ iPad implementation in the classroom The role of efficacy and perceived impact. Interactive Technology and Smart Education, 16(3), 278-299. https://doi.org/10.1108/ITSE-06-2018-0041

Lin, H. F. (2013). The effect of absorptive capacity perceptions on the context-aware ubiquitous learning acceptance. CampusWide Information Systems, 30(4), 249-265. https://doi. org/10.1108/CWIS-09-2012-0031

Ma, H. (2020). Building the training system of physical education innovation ability in higher vocational colleges based on computer information technology. Journal of Physics: Conference Series, 1578, 012064. https://doi.org/10.1088/1742$6596 / 1578 / 1 / 012064$

Martono, S., Mukhibad, H., Anisykurlillah, I., \& Nurkhin, A. (2020). Evaluation of acceptance of information systems in state university with theory of planned behavior and theory of acceptance model approaches. Management Science Letters, 10(4), 3225-3234. https://doi.org/10.5267/j.ms1.2020.6.016

Masrek, M. N., \& Gaskin, J. E. (2016). Assessing users satisfaction with web digital library: The case of Universiti Teknologi MARA. The International Journal of Information and Learning Technology, 33(1), 36-56. https://doi.org/10.1108/ IJILT-06-2015-0019

Muhsin, T. P., \& Nurkhin, A. (2016). Intention to use E-Journal; A unified theory of acceptance and use of technology perspective. IOSR Journal of Research \& Method in Education, 6(4), 100-106. https://doi.org/10.9790/7388-060404100106

Nguyen, O. T. (2020). Factors affecting the intention to use digital banking in Vietnam. Journal of Asian Finance, Economics and Business, 7(3), 303-310. https://doi.org/10.13106/jafeb.2020. vol7.no3.303

Nguyen, X. T., \& Luu, Q. K. (2020). Factors affecting adoption of industry 4.0 by small-and medium-sized enterprises: A case in Ho Chi Minh city, Vietnam. Journal of Asian Finance, Economics and Business, 7(6), 255-264. https://doi. org/10.13106/jafeb.2020.vol7.no6.255

Pal'Ova, D., Vejacka, M., \& Kakalejcik, L. (2020). Project-based learning as a tool of enhancing of entrepreneurial attitude of students. Advances in Science, Technology and Engineering Systems, 5(1), 346-354. https://doi.org/10.25046/aj050144

Park, E., \& Kwon, S. J. (2016). The adoption of teaching assistant robots: A technology acceptance model approach. Program, 50(4), 354-366. https://doi.org/10.1108/PROG-02-2016-0017

Samsudeen, S. N. (2019). University students' intention to use e-learning systems. Interactive Technology and Smart Education, 16(3), 219-238. https://doi.org/10.1108/ITSE-112018-0092

Schöpfel, J., Azeroual, O., \& Saake, G. (2019). Implementation and user acceptance of research information systems; An empirical survey of German universities and research organisations. Data Technologies and Applications. https://doi.org/10.1108/DTA01-2019-0009

Venkatesh, V., Morris, M. G., Davis, G. B., \& Davis, F. D. (2003). User acceptance of information technology: Toward a unified view. MIS Quarterly, 27(3), 425-478. https://doi. org/10.2307/30036540

Wu, C., \& Wu, P. (2019). Investigating user continuance intention toward library self-service technology. Computer Science, 37(3), 401-417. https://doi.org/10.1108/LHT-02-2018-0025

Yadav, R., Chauhan, V., \& Pathak, G. S. (2015). Intention to adopt internet banking in an emerging economy: A perspective of Indian youth. International Journal of Bank Marketing, 33(4), 530-544. https://doi.org/10.1108/IJBM-06-2014-0075 